Cahiers $d u$ MONDE RUSSE

\section{Cahiers du monde russe}

Russie - Empire russe - Union soviétique et États indépendants

$57 / 1 \mid 2016$

Terres, sols et peuples : expertise agricole et pouvoir (xixe - xxe siècles)

\title{
Why did the attempt under stalin to increase agricultural productivity prove to be such a fundamental failure?
}

On blocking the implementation of progress in agrarian technology (1929-1941)

Pourquoi, sous Stalin, la tentative d'augmenter la productivité agricole s'est-elle révélée un échec désastreux? Du blocage de la mise en cuvre du progrès dans la technologie agricole (1929-1941)

\section{Stephan Merl}

\section{(2) OpenEdition}

\section{Journals}

Electronic version

URL: http://journals.openedition.org/monderusse/8343

DOI: $10.4000 /$ monderusse. 8343

ISSN: $1777-5388$

\section{Publisher}

Éditions de l'EHESS

\section{Printed version}

Date of publication: 1 January 2016

Number of pages: 191-220

ISBN: 978-2-7132-2540-6

ISSN: $1252-6576$

Electronic reference

Stephan Merl, « Why did the attempt under stalin to increase agricultural productivity prove to be such a fundamental failure? », Cahiers du monde russe [Online], 57/1 | 2016, Online since 01 January 2019, Connection on 19 April 2019. URL : http://journals.openedition.org/monderusse/8343; DOI : 10.4000/ monderusse. 8343

This text was automatically generated on 19 April 2019

(c) École des hautes études en sciences sociales 


\section{Why did the attempt under stalin to increase agricultural productivity prove to be such a fundamental failure?}

On blocking the implementation of progress in agrarian technology (1929-1941)

Pourquoi, sous Stalin, la tentative d'augmenter la productivité agricole s'est-elle révélée un échec désastreux? Du blocage de la mise en œuvre du progrès dans la technologie agricole (1929-1941)

\section{Stephan Merl}

\section{EDITOR'S NOTE}

Translated from German by Bill Templer

1 The Marxists harboured great expectations of a revolutionising of agricultural productive forces in the transition to a "Socialist" agriculture, which in their conception would be characterized by large-scale enterprises. ${ }^{1}$ The external prerequisites for a rapid increase in hectare yields and a lasting improvement in the output of Soviet agriculture were very good at the end of the 1920s. The Russian experts by then had come to play a leading role in international agrarian research. They had investigated the regional peculiarities of farming in Russia and were in a good position to draft sweeping programmes for agrarian reform. ${ }^{2}$ Economic planning promised to translate new agricultural knowledge more rapidly into production, thus facilitating a substantial rise in hectare yields and animal performance. ${ }^{3}$ Small-scale production was still predominant and displayed a range of serious defects, including strip positioning, numerous border furrows, remoteness of land under cultivation, strip farming (cherespolositsa), primitive technology and a lack of 
adequate knowledge among the producers. The prospect of overcoming these weaknesses promised significant growth in yields, and this also was in evidence in the second half of the 1920 s. $^{4}$

2 This paper seeks to examine why a country with such excellent agronomists in the 1930s did not prove able to implement much of their knowledge in practice in a bid to achieve the rapid rise in per hectare yields which policy desired. The focus here is principally on the measures which had been introduced and pursued with notable success since the 1906 Stolypin agrarian reform: land consolidation, the introduction of progressive crop rotation and the use of a selected seeds. Until now research had paid little attention to the fact that the regime under Stalin continued with these measures and consistently accorded them great importance. Just in the 1930s alone, four large-scale campaigns were launched to implement them. Why then did they fail? What informal institutions acted to prevent the agricultural producers, those in responsible positions in the kolkhozes and in the local party and Soviet state bureaucracy, from introducing the necessary crop rotations? Why did the agricultural producers under Stalin lose interest to such a marked degree in increasing their yields? The investigation of these questions sheds revealing light on the contradictory nature of Stalin's agrarian policy. It highlights the specific structure of this policy and its long-term consequences. The increase in yield per hectare and in animal performance remained comparatively modest in the Soviet Union even after Stalin's death. Poor harvests under Brezhnev would shake the regime anew. ${ }^{5}$

The present essay addresses first the question as to whether agriculture under Stalin can be termed "industrialised agrarian production," as it is sometimes called in the contemporary literature on development policy (section 1). Then it deals in a strictly chronological way with the reaction of the regime in the 1930s to catastrophes in agriculture it had itself created: the loss of control over the soil by forced collectivisation (section 2); the neglect of agricultural technology causing weed infestation in the fields and decreasing yields (section 3); the total neglect of crop rotations in the agricultural enterprises and the blocking of the transition to useful crop rotations by linking the obligatory delivery of grain to the land sown (section 4); the extensive loss in selected seeds undermining the "life in prosperity" that Stalin had promised due to the poor harvest of 1936 (section 5); whom to blame of sabotage for the failure to increase agricultural production and the spread of animal epidemic diseases (section 6); the desire among the agricultural producers to elude "bonded labour" by leaving the kolkhoz and returning to private farming after the good harvest of 1937 (section 7). Finally the paper examines the attempt by the People's Commissar Ivan Benediktov in 1939 to take stock of agricultural policy and development (section 8) and explores the grandiose regional plans for the transformation of nature (section 9). A concluding section discusses the paradoxical character of state action in Soviet agricultural policy (section10).

\section{1-Did collectivisation mean a transition to "industrialised agrarian production" ?}

4 Before the onset of collectivisation, the party had always described Socialist agriculture as fully mechanised large-scale enterprises based on tractor power. In connection with the First Five-Year Plan, the first initial projects were worked out on an experimental basis for establishing model large-scale agrarian enterprises. Especially ambitious were 
plans to bring together agricultural and industrial production in the form of agro-industrial combines and to equalize the divide between living conditions in urban areas and the countryside by means of "agro-cities." ${ }^{\text {Th }}$ The agro-industrial combines, such as those drafted by Ia. Nikulikhin at the beginning of the 1930s, were designed to encompass an area of ca. 20,000 hectares. ${ }^{7}$ Ambitious plans were worked out to settle the nomads in Kazakhstan. ${ }^{8}$ Huge state investments would have been required to realise each of these projects in anticipation of the envisioned future structure of agriculture. At the end of the 1920s, the planners were convinced that the prerequisites to move on to "industrialised" agriculture in a larger-scale framework were not yet given. Consequently, the First Five-Year Plan, even in its "optimal variant" adopted in April 1929, expected that small-scale farming would still remain dominant over the longer term. ${ }^{9}$ Only after industrialisation had created the proper prerequisites would the general transition to large-scale enterprises in agriculture then also gain traction in the mid-1930s. ${ }^{10}$

5 As is well known, the forced collectivisation torpedoed all these plans. It was based in the winter 1929-30 on the massive use of force against the peasants. Collectivisation now no longer aimed at creating well-structured large-scale agrarian enterprises. Rather, with the "struggle for grain," it sought solely to subjugate the peasants, who supposedly were sabotaging Socialist construction. The "dwarf kolkhozes" that arose in the transition to the 1930s usually brought together only a small number of peasant communities, and with approximately 400 hectares of land, had only one tenth of the minimal land area originally planned for the large-scale enterprises at their disposal. In addition, the kolkhozes only possessed equipment for small-scale farming, since mechanised technology from 1930 on was supplied exclusively to state farms or machine-tractor stations. The ambitious projects of individual planners such as Nikulikhin thus came to nought. In view of the striking lack of agricultural technology and the necessity of concentrating the available means for investment in industry, beginnings were made locally to establish some "kolkhoz giants" and to sell off the inventory of the peasants. But since the state did not provide any funding, the enterprises existed solely on paper, and already in the spring of 1930 they reverted once more into individual farmsteads. ${ }^{11}$

6 To date the literature has paid scant attention to the fact that the regime reacted to the famine in 1932/33, which had been caused by the brutal expropriation of the agricultural produce, by introducing a fundamental reform in their agrarian policy. This points up just how dangerous Stalin regarded the situation that had developed. ${ }^{12}$ In order not to jeopardise his rule, he was unable to admit publicly that forced industrialisation and collectivisation had caused a famine with its millions of victims. ${ }^{13}$ The forced collectivisation had been driven solely by the interest of the state to subjugate and expropriate the peasantry. The now established "kolkhoz system" was meant to put an end to the arbitrariness that the agricultural producers had formerly been subjected to. In substance, this was a compromise between the interests of the state and those of the peasants. With the return to the principle of tax in kind through obligatory delivery of agricultural products per hectare or animal to the state, it ensured the state a very high proportion of agricultural produce without having to completely cover the costs of production. In addition, it took the interests of the kolkhoz members (kolkhozniki) into account: with the granting of the right to private plots (and the temporary furthering of maintenance of private productive animals) and a "prepayment of natural goods" during 
the threshing based on achieved labour days (trudodni) as a basis for the income distribution at year's end, it secured the kolkhozniki the possibility to survive. ${ }^{14}$

The "kolkhoz system" was in existence from 1933 until the forced enlargement of the kolkhozes between 1949 and 1953. From its inception, it put an end for the next two decades to all experiments in the direction of an "industrialised" agricultural production. By separating private plots from kolkhoz production, it conserved primitive forms of agricultural production. Under Stalin, the kolkhoz economy remained largely limited to a small number of plant cultures. The production of potatoes, fruit and vegetables and livestock farming was principally on the private plots. The inclusion of cattle breeding within the kolkhozes would have required large investments, inter alia in livestock stables. Since the prices paid by the state did not cover production costs, any increase in production or involvement in new production branches necessarily had to augment the losses of the kolkhozes (and thus the unpaid compulsory "bonded labour" demanded of its members). ${ }^{15}$ With collectivisation, the enterprises lost control over the quality of field cultivation, since that was increasingly taken over by the machine-tractor stations (MTS). Tractors were supplied solely to the MTS and remained state property. Mechanisation served principally for purposes of control, and in conjunction with the political departments established in 1933, functioned additionally as a means to discipline the kolkhozniki, but did not assist in modernising agriculture. From the mid-1930s on, grain was thus expropriated directly on the fields, circumventing the kolkhoz storage barns. ${ }^{16}$ For the most part, both the MTS directors and the kolkhoz chairmen lacked even elementary knowledge of agriculture production. Their function was mainly to execute what the party ordered while intimidating their workforce. ${ }^{17}$ In many areas of work, manual labour predominated. There were no new approaches to making the heavy work, performed principally by females, any easier. ${ }^{18}$ Only after Stalin's death was the project of "industrialised agricultural production" given new life, revived in the 1960s. ${ }^{19}$

8 At the end of the 1920s, per hectare yields in plant cultivation and animal performance were still very low in the Soviet Union in comparison to other European countries. Instead of rising, they even worsened in the $1930 \mathrm{~s}^{20}$ This presents a devastating picture of the performance of the large-scale Soviet agricultural enterprises. In the case of grain and potatoes, the hectare yields were on average some $15 \%$ gross below those of the small-scale farmsteads. In the case of sugar beet and cotton cultivation, the yields in the first half of the 1930s declined even further. From 1935 on, they recovered and quickly rose, although not reaching the pre-1914 levels. Rising yields of sugar beets and cotton were based on a drastic increase in producer prices, which then covered the production costs incurred. In the case of sugar beet cultivation, small work teams were organised; these units were responsible for all working operations. In the cotton kolkhozes, the kolkhoz members received cash payments from 1935 on large enough to enable them to cover their food needs by purchases in the marketplace. ${ }^{21}$ By contrast, in the case of potatoes and grain, the prices paid by the state for the compulsory delivery of produce ultimately covered only some $20 \%$ of production costs. ${ }^{22}$

\section{2-The forced collectivisation 1929-1932 : Loss of control over the soil}

9 It was counterproductive to commence with the desired acceleration of the development of agricultural technology by compulsory making an extensive change in agrarian 
structure. The abrupt replacement of small-scale farming by kolkhozes and state farms stripped all previously achieved success in land settlement (zemleustroistvo) and land consolidation of its basis. It was necessary to start all over again from the beginning, and even that could not be done unless the situation with land for the new enterprises had been stabilised.

The party leadership was initially convinced that tractors and large-scale farming would guarantee progress in agricultural technology: the tractor was expected to solve all agricultural-technological questions. ${ }^{23}$ They consciously accepted the concomitant destruction of peasant means of production, because that loss would be "compensated a hundred times over by the huge advantages that we shall gain through the new Socialised forces of production." ${ }^{24}$ Speaking before the November plenary in 1929, Molotov explained that financing would be achieved through the expropriation of the peasants during collectivisation. ${ }^{25}$ However, he did not explain how investments could be financed from this, since peasant inventory would necessarily lose its total market value. In practice, land consolidation and settlement constituted the prerequisites for achieving improved working of the fields through the use of tractors. In addition, development in the agricultural sector was burdened by the fact that the party did not return to the principle of "one-man leadership", as it had done in 1931 in the case of industry. Rather, given its profound distrust of the peasantry, the party interfered constantly in the agricultural production process. It sought to control each and every activity. Furthermore, until his death, Stalin resolutely adhered to the idea of demanding a "tribute" from the peasants for the industrialisation. ${ }^{26}$

11 Agrarian experts such as Moisej Vol'f, who was among the designers of the first Five-Year Plan for agriculture, publically expressed their reservations regarding hasty collectivisation and their fears about dramatic consequences due to rural overpopulation. Under Stalin's regime, which did not countenance critical suggestions, they had to pay a high price. At the highpoint of the famine in early 1933, Vol'f was arrested and executed soon thereafter. ${ }^{27}$ In actual fact, the introduction of forced collectivisation in the winter of 1929/1930 was implemented without any organisational preparation. The party leadership did not articulate its initial ideas on elementary questions, such as how in their view a kolkhoz should function, until March 1930 with the publication of the Agricultural Artel Statutes. The fact that some peasants refused to join the collective enterprise despite continuing pressure ${ }^{28}$ increased the confusion as to what land the kolkhoz could have at its disposal.

12 With forced collectivisation, the decisive prerequisite for the introduction of crop rotation was lost for a long period. To achieve that goal, the land would have had to be allotted to clearly designated enterprises for at least the duration of three crop rotations. Due to their virtual obsession with the aim of breaking the resistance of the recalcitrant peasants, the party leadership initially failed to recognise the dangerous side effects of their policy. The local authorities were no less arbitrary in allotting land to the kolkhozes than in dealing with individual peasants. In their eyes, the dwarf kolkhozes enjoyed no protection, since they were not in keeping with the large-scale enterprises that were the primary goal. For that reason, local authorities resorted to applying pressure in order to force the merging of kolkhozes. In 1932 and 1933 they tried to merge all enterprises served by a single MTS into a large kolkhoz..$^{29}$ Since the actual development of hectare yield depended on the available tractive power, the phasing out and demise of work horses exacerbated the situation even further: agricultural productivity slumped and the 
poorly cultivated croplands were covered in weed. In the 1930s, the supply of tractors did not compensate for the loss in animal horse power. It was not until the 1950s that the level of tractive power of 1928 was reached again and subsequently exceeded on a lasting basis. $^{30}$

In practice, taking grain for delivery to the state had unconditional priority. The law "On the Protection of Socialist Property," drafted by Stalin personally in August 1932, extended the property claim by the state on grain already in its stage of growth ripening on the fields. Consistent with this, in 1933 the statistical harvest survey was revised. Instead of being classified as "barn harvest," now the term "biological harvest" was applied to everything that had matured in the fields up to the point of harvesting. ${ }^{31}$ As a consequence, all harvest losses were now at the expense of the kolkhoz members. Depending on climatic conditions, the losses ranged between 20 and $30 \%$. In the summer and autumn of 1932, some starving kolkhozniki were shot in accordance with the new law, because they had stolen ears from the fields. The local state authorities quickly understood that they were obliged to deliver grain to the state under all circumstances. For that reason, they had neither interest in nor understanding for the measures of land consolidation. The only thing that mattered to them was a short-term demonstrable success. Short-sighted, they thought just as little as the party leadership about the foreseeable long-term consequences and ultimate costs of their actions.

\section{3-Kolhhoz system and crop rotation: The first campaign for land consolidation 1932-1935}

In the autumn of 1932, the party and government endeavoured to bring some order into the arbitrary practices of land allotment. They accused the local authorities of having acted on their own in channelling off kolkhoz land for setting up state farms or other state purposes, and of having changed the boundaries between the kolkhozes without their approval. Boundary changes from now on were only to be permissible if at least three-fourths of the members of the kolkhoz affected had agreed and changes had been subsequently approved by the Oblast' Land Department. ${ }^{32}$

The party leadership became aware that improvement in cultivation techniques constituted a prerequisite for increasing hectare yields. This recognition made them dependent on the experts who alone could work out scientifically grounded crop rotation schemes. However, they also mistrusted these experts. ${ }^{33}$ In 1932, the party leadership ordered a land settlement campaign and the introduction of crop rotations. However, in an atmosphere still marked by measures of brutal compulsion against the peasants, they neglected to create the conditions for the successful implementation of their directives. The brief deadline they stipulated ignored the fact that land consolidation together with the reaping of crop rotation fields inside the enterprises was labour-intensive and associated with various expenses. However, the party leadership sought to curb the local authorities in their arbitrary approach to the existing kolkhozes and to grant the latter a conditional guarantee of continuance in regard to the land allotted to them.

The "kolkhoz system" made it more difficult to introduce crop rotations. Since a tax in kind on the land sown had to be paid, the interest of the local authorities and the party leadership in the struggle for grain now concentrated on the area of land sown in grain. However, every introduction of crop rotations designed to increase yield necessarily 
presupposed some reduction in the area of land for grain cultivation. Hectare yields and thus the grain harvest as a whole would have indeed clearly increased. Yet this correlation was too complicated for a control based on compulsion. For that reason, in practice every crop rotation that limited the area of land for sowing grain was deemed a crime against the state. As a result, the professional execution of their work locally became a challenge fraught with incalculable risks for the agrarian experts.

The first campaign to introduce crop rotation was carried out solely on paper. The compulsion exerted by the party did result in 1935 that for some $80 \%$ of the kolkhozes, "crop rotations" were registered in the files of the agricultural authorities. But in practice they were not heeded. In many instances, enterprises were not even aware of such registered rotations and they were not in keeping with the plans for sowing. Since in many areas kolkhoz members were going hungry and there was a lack of any order whatsoever in the kolkhozes, land surveyors (zemlemer) had initially not even gone to the kolkhoz enterprises. Given the pressure under which they worked themselves, they rather immediately reported to their superiors about the successful implementation of the measure.

In May 1933, at the very highpoint of the famine and death by starvation, the People's Commissariat for Agriculture (NKZ) criticised that when arranging the crop rotation fields for the kolkhozes, the "hunt for quantity was proceeding apace at the expense of quality." Work was being done sitting at office desks. They were not ensuring any increase in yields, because they did not proceed from the differing fertility of the individual land plots, and in many cases even included land that could not be sown and cultivated at all. ${ }^{34} \mathrm{~A}$ report in 1935 sketched a bleak picture of the quality of work performed. As a rule, the crop rotation fields were registered on antiquated file cards, in part stemming from the 1860s, without any local check of the actual situation on the ground. The areas of land registered frequently did not jibe with the actual boundaries of the kolkhozes and took neither meadows nor grazing land into account. ${ }^{35}$ Surveyors described the situation as follows: the kolkhozes were not masters over their own land. The plan for sowing was worked out in the raion centre at someone's desk, the machinery from the MTS arrived when it was the respective kolkhoz's turn, and the machines employed were often too heavy for the soil. ${ }^{36}$ Pictures of soil conditions in the Sofanovo Raion (West Oblast') taken by staff workers of the Research Institute for the Organisation of the Territory document that in many instances, grain was planted on boundary soils that permitted only very low hectare yields. Cultivation of this land was nothing but a sheer waste of seeds and labour power. ${ }^{37}$

\section{4-The transfer of land to the kolkhozes "for unlimited use, i.e. in perpetuity"}

In 1935, times appeared favourable for stabilising conditions likewise in the countryside. Collectivisation had been concluded, aside from a few "retirees" who restricted themselves to self-support. ${ }^{38}$ After a phase of severe social upheaval and heavy repression during forced industrialisation and forced collectivisation, a certain level of stabilisation emerged. Naum Jasny speaks of the "three good years" 1934-1936, in which a high level of industrial growth was achieved and the standard of living, which had declined markedly in the early 1930s, was again on the rise. ${ }^{39}$ With his encouraging appeal: "Life has improved, comrades. Life has become more joyous!," Stalin sought to bolster up the 
population, infusing them with renewed courage, and invited them to hope for a "prosperous" life in the foreseeable future. ${ }^{40}$ The actual achieved current state in the building of "Socialism" was formalised in the "Socialist" 1936 Constitution of the USSR.

At the 2nd All-Union Congress of the Kolkhoz Shock-Workers in February 1935 in Moscow, Mikhail Chernov, the People's Commissar for Agriculture, reminded his audience that Stalin in 1933 had set the goal of making the kolkhozniki prosperous. ${ }^{41}$ In the Kolkhoz Statutes passed by the Congress, he now combined this goal directly with improving cultivation techniques and the introduction of crop rotation fields. ${ }^{42}$ Iakov Iakovlev, who had advanced to Central Committee Secretary for Agriculture, noted that there was still a substantial lack of clarity as to what land belonged to what kolkhoz, and he castigated the illegal changing of kolkhoz boundaries, a practice still widespread, in which land was allotted to other kolkhozes or to state farms. ${ }^{43}$

The new Kolkhoz Statutes included precise regulations for land use. The land should be assigned to the kolkhoz as a closed area of usable agricultural land, while excluding any elements that might give rise to a conflict situation. The land remained state property, but the kolkhozes were now to receive it "for unlimited use, i.e. in perpetuity." The state certificate concerning its land was to be presented to the kolkhoz in a special ceremony. This certificate should specify the size and precise boundaries of the land assigned. After that, any reduction in the surface area was not permissible, but enlargement was possible by means of land from the state fund or land from individual peasants. The Kolkhoz Statutes demanded that the land be divided into crop rotation fields and that specified sections be allocated to each field brigade for the entire duration of a crop rotation. ${ }^{44}$

It becomes clear to what extent this spectacular decision to hand over the land to the kolkhozes "in perpetuity" was born out of necessity to finally overcome the continuing chaos in the allotment of land and the definition of its boundaries. This is evident when we note how distant actually existing kolkhozes were from what experts had regarded in 1929 as the ideal Socialist large-scale enterprise ("agro-industrial combines"). Many of the dwarf kolkhozes that had emerged were too small to employ tractors and combine harvesters in an optimal manner.

The fact that it was not until the mid-1930s when the external boundaries of the kolkhozes were established at all underscores the level of chaos created by the forced collectivisation. In part, the land of the kolkhoz was located ten or more kilometres from the economic centre of a given kolkhoz. The schematic drawings on land available to the raion land authorities indicated too great an area of land for many kolkhozes. The sowing plan then demanded to cultivate more land than they actually had available, and also to deliver grain from that (non-existent) land area as well.

Management, planning and control over land settlement were now transferred to the NKZ. The departments for farmland arrangement in the local land authorities were assigned the task of drafting the concrete measures for local land consolidation and the introduction of crop rotation. ${ }^{45}$ The official state certificates were to be issued only after conclusion of the land consolidation and the elimination of all deficiencies. The external boundaries of the kolkhoz had to be clearly marked by boundary posts and confirmed by the assembly of the kolkhoz members. ${ }^{46}$

In conjunction with the new survey of land between mid-1935 and mid-1937, there was also a handover of non-utilised land of the state farms to the kolkhozes. Smaller and in particular non-profitable state farms were totally dissolved. ${ }^{47}$ In this way, the state rid 
itself of such state farms that previously had only incurred losses, and at the same time forced the kolkhoz members to assume the cultivation of these largely exhausted and leached out areas of land. The kolkhoz was obligated to deliver grain as a natural tax "in kind" to the state. This was a good arrangement for the state: it continued to receive the grain, but because the kolkhozniki were now producing it, the state no longer was required to cover the costs of production. In addition, the state extorted money from the kolkhozniki, because they had to pay for the valuables of the dissolved state farms which they had taken into possession: the conventional price had to be paid for mother animals, and in the case of buildings, the carrying value of the property, while deducting for depreciation. ${ }^{48}$ The archival material is silent about the prevailing mood among the kolkhoz members under this dispensation.

Work on surveying the land and the associated issuance of state certificates dragged on far longer than originally planned, since now there was actually an attempt to carry out farmland arrangements locally. The evident contradictions in policy were not discussed publically: namely that crop rotations could only be successfully implemented if the enterprises were left certain freedoms for action, and that in grain cultivation, the state was demanding unpaid forced labour from the kolkhozniki.

A more primitive technology was employed in 1936 on the kolkhoz land in the West Oblast' than before in the small-scale farmsteads. The loss of horses had scarcely been compensated by the supply of tractors in the non-Black Earth Region. As a result, the capacities for implementing fieldwork had declined dramatically. ${ }^{49}$ In other regions as well, there were encroachments on the kolkhozes in order to force them to greater deliveries of grain after the poor harvest of 1936. According to Iakovlev, the Central Committee Secretary for Agriculture, the sowing plans in Krai Saratov inter alia violated the crop rotations in many places. Several raions forced the kolkhozes to sow grain in soil that was evidently unsuited for cultivation. It was said they were for that reason chronically in arrears with their deliveries to the state..$^{50}$ In the Leningrad Oblast', in the autumn of 1936 the area of land registered as a kolkhoz sowing area exceeded the actually existing land by some $10 \% .^{51}$

The experts on the spot locally were very dissatisfied due to the contradictory nature of the central directives issued at the same time. At the Kolkhoz Department in the Research Institute for the Organisation of the Territory, a consultation was convened in early February 1937. ${ }^{52}$ Mikhail Semenov, Senior Engineer in the Leningrad Department for Land Settlement, criticised the introductory lecture that had been given: he thought it was too abstract, divorced from reality and had not dealt with the problems in the north. He noted that he had been assigned the task of introducing crop rotations in 1937 for 4,500 kolkhozes on 1.2 million hectares. He stated that this was impossible if scientific requirements were to be met. In addition, he stated that no kolkhoz was prepared to pay the fee of six to seven roubles per hectare for this. ${ }^{53}$ Maslov (Saratov) pointed out that crop rotations had already been introduced in 1935. He noted that the material in the raions was based on that. Maslov stressed that to that extent, the question of what crop rotation the individual kolkhoz should receive had already been decided on in advance. Moreover, the Raion Land Department was proceeding on the assumption that the area of land registered for the individual kolkhozes actually existed. Now it was evident, he added, that the agronomists in 1935 had decided on the crop rotations without knowledge of the quality of the soil, and that many of their calculations were incorrect. A substantial portion of the land declared in 1935 to be suitable for grain could, he noted, be used in the 
best case only for grazing pasture. His farmland arrangement team now had to transform $50-60 \%$ of the land area allotted for growing wheat into crop rotation areas for forage grass instead, because the soil structure was not suitable, and the team had to correct the specialisation of the kolkhozes. "We just don't know at the moment how we can solve these problems." He asked: did the NKZ have to issue the permit? If they classified too much land as unsuitable for grain cultivation, that move would be viewed as an "anti-state activity." ${ }^{4}$

\section{5-The extensive loss of selected seeds after the poor harvest 1936}

The poor harvest of 1936 served to spotlight a second unsolved problem alongside the introduction of crop rotation: how could selected seeds be protected if after every harvest, delivery of grain to the state had absolute priority? As a result of the rigorous amassing of grain by the state, in 1936 a substantial proportion of the selected seeds ended up in the state grain mills. ${ }^{55}$ The party's attention was called to this during preparations for the spring sowing campaign in $1937 .{ }^{56}$ In customary style, it blamed scapegoats for the problem. In June 1937, the Central Committee (TsK) plenary strongly criticized the chief administration for grain within the NKZ. It alleged that this administrative body had sabotaged the task of the Five-Year Plan and opened a door to the possibility of introducing poor seed varieties. It stated that for all practical purposes, good peasant seeds had disappeared. The TsK claimed existing selected seeds had been partially ground in the mill due to insufficient marking and had been mixed with other seeds in the state warehouses. It argued that the NKVD (People's Commissariat of the Interior) and the courts would have to clarify now where bureaucratic error ended and criminal "wrecking" appeared. ${ }^{57}$

From 1939 on, all kolkhozes and state farms were permitted only to use selected seeds that were adapted to the local conditions. In 1937, the state was finally prepared to assume full financing of the state selection stations. ${ }^{58}$ In addition, material incentives were created: beginning in 1937, selection stations and plant breeders were to be given a special award by allowing them to participate in the profits gained by varieties they had helped to breed or improve. Several penalties were instituted to put an end to their misuse of selected seeds. Misuse for an unintended purpose would be punished by two years forced labour, while mixing of selected grain seeds would even entail a penalty of up to three years forced labour. ${ }^{59}$ The rigorous penalties came into effect already in the autumn of 1937. Kolkhoz chairmen, weight recorders and bookkeepers were sentenced to imprisonment and forced labour because they had declared simple seeds to be selected seed varieties. ${ }^{60}$ The seed- producing kolkhozes would also be rewarded by paying them double the state price for grain. ${ }^{61}$ Yet this was unable to spur an incentive for production. Even if this compensated the kolkhozes for $40 \%$ of production costs instead of just $20 \%$, the bottom line here was still that the kolkhozes were not being totally paid for what they were producing.

31 The disconnect with reality is underscored by the fact that the "quality standards" for seed lowered in November 1935 by the NKZ became the target of sharp critique. By that move, the NKZ had sought to bring standards more into line with the actual condition of the selected seeds, and had therefore increased permitted weed infestation to $0.5-1 \%$. It

Cahiers du monde russe, $57 / 1$ | 2016 
had even increased the permitted level of infection with grain blight by a factor of 20 . From now on, the grain distributed by the State Fund for Selected Seeds was once again supposed to be totally free of blight and weed seeds. ${ }^{62}$ Many leaders of the State Fund were dubious about the prospects of adhering to these norms. In numerous instances, "selected seeds" provided to kolkhozes in the obligatory exchange were actually inferior to the seeds which the kolkhozes had to deliver in exchange. ${ }^{63}$

The decree did not improve the selected seeds available. Large amounts continued to lose their germination capacity due to poor storage conditions in the State Fund facilities. At the end of $1937,67 \%$ of the wheat seed in the kolkhozes in Ukraine were contaminated. ${ }^{64}$ A substantial portion of the seed for sowing in 1938 was infested with mites or contaminated, in many cases it had but a very low germination capacity. ${ }^{65}$ In early 1939, Benediktov pointed to a further cause of the calamity: there was a lack of proper sheds for storing the selected seeds. He accused the State Planning Commission of not having provided sufficient investment funding for construction of storage space. ${ }^{66}$

After the poor harvest in 1939, the party and government once again rescinded their threats of penalties in connection with the protection of the selected seeds. This more easy access to seed enabled the local organs of authority to fulfil their obligation to deliver grain to the state. ${ }^{67}$ In 1940 , the MTS units even encouraged their tractorists not to adhere to the regulations of agrarian technology, so as not to endanger the full implementation of the plans for sowing in view of the reduced norms instituted for fuel consumption. ${ }^{68}$

\section{6-The execution of the cautioners : Agronomists as scapegoats}

Many agrarian experts were murdered in 1937 and 1938 because the party leadership blamed them for the miserable production results. The poor harvest of 1936 had once again set back the agricultural sector. The "prosperous life" that Stalin had promised thus receded into a seemingly distant future. The transition to terror in agriculture was also based on the contradictory directives for the issuance of state certificates: on the one hand, they were intended to formalise and codify crop rotations grounded on solid science, while on the other, the surface area for grain cultivation was not permitted to be reduced in the sowing plans. It was impossible to achieve both aims simultaneously. This contradiction in the dictatorship could not be discussed publically and thus could not be resolved. In order to deflect attention from the responsibility of the party leadership, concrete individuals in the state bureaucracy were scapegoated, accused of wrongdoing. ${ }^{69}$ The failure to increase yields was portrayed as the failure of experts in the land authorities and the NKZ. Only after almost all the experts had been executed in 1938 and the hectare yields nonetheless had not increased was there in 1939 a half-hearted change of direction in policy, yet policy continued to adhere to state compulsion against agricultural producers.

The terror had specifically targeted those individuals who had tried to implement the party directives of 1935 on the introduction of scientifically grounded crop rotations. The fact that the West Oblast' was chosen to be made an example had to do with the poor suitability of soil there for agriculture and the spread of small kolkhozes as a consequence. Many kolkhozniki in the West Oblast' still lived on individual farmsteads, 
so-called khutory. The introduction of crop rotation threatened a drastic reduction in the grain cultivation area. This would have decreased the obligatory delivery of grain to the state, but would have nonetheless caused local grain production to increase due to higher hectare yields. The First Party Secretary in the West Oblast', I.P. Rumiantsev, was now portrayed to be a "wrecker." He was pilloried and charged with total blame before the eyes of the population. There is no reason to give credence to these charges and to make a purported "weakness in the rural bureaucracy" responsible for the mistakes. ${ }^{70}$ In April 1937, the paper Izvestiia sounded an alarm regarding these "anti-state practices" rife in the West Oblast': it alleged that the soil was "disappearing" there in numerous raions. It charged that "wreckers" were active, seeking to sabotage the state plan of grain sowing using all means available, and to that end, they were falsely describing "fertile farmland" as grazing pasture, swap or thick brush land. ${ }^{71}$ Rumiantsev and many staff members in his Oblast' administration were relieved of their duties on 17 June 1937, subsequently arrested and soon thereafter executed..$^{72}$ The Moscow party leadership pilloried these individuals, making an egregious example of them across the Soviet Union, supposedly responsible for the exceptionally poor production results in the kolkhozes. In local show-trials, the population was presented with their "activity as parasites" in the issuance of state certificates. The West Oblast' party leadership was accused of having artificially caused unrest by having rejected (for formal reasons) complaints against the establishing of fixed boundaries for kolkhozes and separating off land from kolkhozes set up for various nationalities. The Oblast' leadership was also accused of having allotted land to kolkhozes which was located at a great distance from the kolkhoz centre or had been assigned to other kolkhozes. It was claimed that many kolkhozes had lost their meadows, original private plot land and gardens. ${ }^{73}$

In view of the evident priority that the party leadership accorded land for grain cultivation, comments by the People's Commissar for Agriculture Chernov speaking before the TsK plenary in 1937 caused some dismay. He could not mention in particular that this demand was incompatible with the order for introduction of genuine crop rotations. Consequently, he simply acted as if this contradiction did not exist at all, and subsequently paid for that with his life. ${ }^{74}$ Before the plenary, Chernov criticised that economically efficient kolkhozes were still being excessively overburdened and for that reason did not develop any interest in increasing yields per hectare: "If a kolkhoz does not fulfil the sowing plan, its obligation is transferred to the other kolkhoz." 75 He cited many examples where the sowing obligations assigned exceeded the actual fields cultivable after crop rotation by up to $30 \%$. In individual cases, the sowing obligation assigned to kolkhozes even exceeded their entire available land area. In the West Oblast', kolkhozes had been required to sow grain for four consecutive years, in areas for cotton cultivation they had been obliged to plant cotton for seven to eight years in succession. This, he stressed, could explain the low yields per hectare. Consequently, Chernov raised the demand that every official should be brought to trial who had imposed a sowing plan on the kolkhoz that violated the crop rotation. ${ }^{76}$ The issue of the inherent contradiction between the central instructions for introducing crop rotation and requirements for grain delivery to the state was solved by means of state terror: Chernov was arrested soon after the plenary on 7 November and later executed as an "enemy of the people."

37 A long report by the NKVD on "Wrecking in Agriculture" assigned the experts blame for the fact that productivity in agriculture had not risen. They were charged, as "wreckers," with having intentionally brought about the catastrophic conditions. ${ }^{77}$ The report peaked 
in the assertion that the head of the NKZ Department of Finance had confessed that the agronomy experts had intentionally devised and introduced a harmful system of crop rotation. In 1937, he noted that the Planning Finance Department had been cleansed of enemies of the people, but that Chernov had actually only replaced former "wreckers" by new ones drawn from the Research Institute for Agroeconomy. ${ }^{78}$ Those individuals had intentionally spread animal epidemic diseases in a bid to sabotage the construction of large-scale livestock breeding. The dissolving of state farms in 1936 was now likewise classified as the result of "activity by wreckers." The "enemies of the people," it was alleged, had especially targeted the land authorities, and to that end had taken over the direction there from the People's Commissar all the way down the ladder into the land departments at the level of oblast' and raion..$^{79}$ The regime concentrated its total energy on exposing the "human parasites" that it could present to the population. This was in keeping with the ideology, according to which the class enemy was seeking to undermine Socialist construction by all available means. The animal husbandry enterprises set up on orders from the state proved to be an ideal breeding ground for epidemics. In 1936, in 44 of the 66 state farms for livestock breeding that were inspected, animals were found suffering from brucellosis or other livestock epizootic diseases. ${ }^{80}$ With the transfer to the kolkhozes of infected animals as breeding animals, the diseases spread to animals not yet infected. The livestock specialists were accused of having intentionally conspired to spread the epidemics.

The terror against top-echelon functionaries initially targeted the head of the Department of Agriculture in the TsK, the former People's Commissar for Agriculture Iakovlev. He was arrested on 12 October 1937. This was followed a few weeks later by the arrest of the incumbent People's Commissar for Agriculture, Chernov. Already earlier, his decrees, such as the attempt to reduce the difference between the actual concrete harvest and the officially registered "biological" harvest, had been declared to be "parasitic wrecker activity." His successor Robert Eikhe was likewise targeted after but a few months in office. On 29 April 1938, Eikhe was arrested. All three were shot and the authorities for land were "cleansed" of their experts in a bid to suggest to the population that they had been responsible for the fact that the "prosperous life" Stalin had promised had not yet materialised. The only one of the People's Commissars for Agriculture surviving the terror was Benediktov, who succeeded Eikhe in April 1938. He was to die a natural death at the age of 81 . Benediktov had remained in office down to the death of Stalin, some 15 years.

\section{7-Bonded labour : Why the kolkhozniki did not want to stay in the kolkhozes}

39 After the good harvest of 1937, several kolkhoz members, for the first time since the forced collectivisation, received sufficient grain for their "labour days" to cover their own needs. Their reaction shocked the party leadership. A substantial number of them wished to use this possibility as a door to escape from the forced institutional framework of the kolkhoz and the "bonded labour" demanded there by the state. A return to individual farming held out the promise once again to be able to determine their own fate. The prerequisite for that consisted in the ownership of a horse, denied to the kolkhozniki. It made the former kolkhoz member in the Soviet village under Stalin into an independent small-scale entrepreneur, opening up excellent possibilities for new 
income. That was because many in the countryside, including state enterprises, were badly in need of transport services. The fact that families with many children also declared their formal resignation from the kolkhoz, because as kolkhozniki they were unable to feed their children, should have put the state to shame. ${ }^{81}$ In 1938 , the party leadership reacted with alarm to these reports. ${ }^{82}$ It shifted the blame for the low payments given to the kolkhozniki to the local party and Soviet state officials..$^{83}$ Stalin was upset that the kolkhozniki were able to escape from the seemingly total blanket of state control by means of resignation. ${ }^{84}$ In his provocative manner, he asked the TsK members in 1939 whether they actually desired to return to small-scale private farming, and at the same time accused them of bearing responsibility for this trend through their own attitude of indifference. He called for putting the brakes in proper time on the rush back to private small-scale farming: Stalin noted that if the kolkhozes were to collapse, the individual peasant would no longer need a tractor or combine harvester to work his small plots of land. In his quasi-natural private enterprise, he would be "reigning as the king on his farmstead." ${ }_{85}$ In addition, Stalin recommended that the "do-nothings," kolkhozniki who earned only a few or no "labour days" in the kolkhoz, should be transferred to other kolkhozes. ${ }^{86}$

Instead of asking about the underlying causes for the catastrophic living conditions in the kolkhozes, the party reacted in 1938 and 1939 by resorting to renewed measures of compulsion. A campaign against the "exclusions" of kolkhoz members was launched and the horse tax was jacked up so much that no private person could any longer maintain a work horse. ${ }^{87}$ In particular, in 1939 the party began with two large-scale inhumane campaigns that worsened once more the living conditions of most kolkhozniki. In May 1939, they launched the struggle against the "illegal extension of the private plots." All areas of land that exceeded the size permitted by the statute were separated off. At the same time, the animals maintained in personal ownership that exceeded the regionally permissible number of productive animals were requisitioned. However, under the pretext of land consolidation, the campaign targeted in particular the 821,000 individual farmsteads (khutor), particularly in the westerns areas of the Soviet Union. They were to be resettled by force into the central locality of the kolkhoz. ${ }^{88} \mathrm{~A}$ forced resettlement into the cotton kolkhozes based on similar pretexts targeted millions of mountain peasants in the irrigations zones in the Caucasus and Central Asia. ${ }^{89}$ This meant that millions of people were deported into the central locality of the kolkhoz in an attempt to finally eliminate the still extant remainders of individual small-scale farm holdings. The resettlement was carried out in 1939/1940 with unimaginable brutality. Its implementation concentrated on elimination of the khutors. Those persons affected had to deal by themselves with reconstructing housing in the central settlement of the kolkhoz. The funding promised to help build up the new settlements was never paid. ${ }^{90}$

41 The totally insufficient pay, aggravated by the highly seasonal nature of their labour, caused many kolkhoz members to seek paid employment outside the kolkhoz, or also to revert to their private plot and concentrate on that. ${ }^{91}$ As nominal "co-owners" of their kolkhoz they only received so-called "labour days" in the registry. These were worthless dashes on paper marking their proportion in "income distribution" at the end of the year, while in the neighbouring kolkhoz, they were paid in cash for the same work as day labourers. Since most of the non-cotton-growing kolkhozes did not earn any profit, they were unable at the year's end to distribute anything to their members. Exemplary for the situation in the kolkhozes was remuneration in Artel Grechiskino near Starobel"shchina 
in Ukraine. A "labour day" in the fields in 1940 earned the labouring kolkhoznik just 64 kopeks. Even the 1.14 roubles per work day in animal production was scarcely more than a sorry pittance. Only in viticulture was their labour actually worthwhile, earning 8.40 roubles for a "labour day." All annual reports of the kolkhozes reveal similar data. Rural dwellers achieved most of their income qua kolkhoz by means of small sales in the bazaars and open markets. A day working on the small farmstead resulted as a rule in a clearly higher income than a formal "labour day" in the kolkhoz. ${ }^{92}$

\section{8-Benediktov's sober assessment of the failure to increase yields}

Work on the Third Five-Year Plan was delayed and begun late, due to the considerable losses in trained workers within the planning bureaucracy as a consequence of the terror. Government policy adhered to introducing crop rotations in an effort to increase yield per hectare. Benediktov, the new People's Commissar for Agriculture, also wanted to quickly improve agricultural production. He appeared to be more concerned to ensure that the state programmes did not just remain words on paper and that crop rotations would actually be implemented in the kolkhozes. Since the state sowing plans prevented the kolkhozes in practice from adhering to their crop rotations, it is initially impressive that Benediktov managed to arrange that no state sowing plan would be set up for 1940 . Rather, it was decided that the kolkhozes would themselves determine their sowing arrangement in keeping with their crop rotation. The law stated:

[...] to promote the initiative of the kolkhozniki in conjunction with the further bettering of grain yields, to strengthen the responsibility of the kolkhozes for planning the sowing of individual grain cultures, and to include the broad mass of the kolkhozniki in planning. ${ }^{93}$

It was possible to interpret that as a concession by the party leadership to the position of the agrarian experts. The latter were convinced that success in raising yield levels was dependent largely on the producers themselves. Yet even now the actions by the party remained ridden with contradiction. The plan for delivery to the state was not altered, and it continued to order the kolkhozes in detail as to what set quantities of the individual cultures they were obliged to deliver to the state, no matter whether their crop rotation made provisions for their actual planting or not. ${ }^{94}$

Benediktov's memo on the Third Five-Year Plan submitted by Gosplan in March 1939 sketches the vision of a new beginning, because for the first time it openly addressed the lack of material incentives for the agricultural producers and the insufficient state investments as problematic issues. ${ }^{95}$ Moreover, the memo, in its blunt stocktaking of the failures of the past decade, suggested cautiously what the actual causes behind this were, springing from the state system of compulsion. ${ }^{96}$ Benediktov evidently considered the lack of material incentives for the agricultural producers and the burdens placed on the largely insolvent kolkhozes as a major problem for the implementation of agro-technical progress. He demanded that at least the basic costs for agrarian modernisation should be covered and borne by the state budget. There is a hint at more realism in Benediktov's suggestion that there should be more extended deadlines for completing work. But in the memos and papers available, he did not comment on the actual problems, namely the state-determined producer prices that did not cover production costs, especially for grain 
and potatoes, and the state measures of compulsion that had turned the kolkhozniki into veritable bonded labourers. ${ }^{97}$

Benediktov also called for resolute measures to strengthen work discipline in the kolkhozes. He demanded the creation of small work teams responsible for the entire production process in dealing with technical cultures, pointing to the successes that had been achieved since 1935 in this way. He noted that material incentives were important in order to better motivate the kolkhoz members, as the government was indeed providing, as a bonus in connection with sugar beet cultivation. ${ }^{98} \mathrm{He}$ stressed that in this way the high degree of labour fluctuation could also be countered and labour productivity increased. In this, Benediktov's ideas recall to some extent Stalin's recommendation on struggling against fluctuations in industry, conceptions he had put forward in his speech to economists in 1931 on "new tasks in economic construction." Benediktov insisted that the state had to cover all costs associated with land consolidation within the enterprises. In his view, in order to end the substantial level of fluctuation due to low wages, the land surveyor had to be put on an equal footing with the agronomists in the land departments at the raion level, and their salary had to be increased from 200 to 700 roubles. ${ }^{100}$ His report, especially prepared for Stalin and Molotov in March 1939, underscored the importance that Benediktov accorded to the introduction of the correct crop rotations. ${ }^{101} \mathrm{He}$ stressed that land consolidation and working out of the crop rotations had to be carried out with active hands-on participation in the process by the kolkhoz management and the kolkhoz activists. This was to occur under the responsible leadership of the agronomist together with the land surveyor, the livestock and other specialists. ${ }^{102} \mathrm{He}$ criticised the fact that between 1932 and 1934, the kolkhozniki had not participated in the drafting of the crop rotation plans, and that the land authorities had often issued obligations for sowing that violated the crop rotation of the kolkhoz. Benediktov announced that the crop rotations for individual branches of the economy would be regulated by special directives. ${ }^{103}$ Noteworthy is the fact that Benediktov laid down a comparatively long final deadline of seven years for concluding with the enterprise-internal farmland arrangement. Only at the end of 1944 would it be possible, he reasoned, to finish work likewise in the peripheral areas. This underscores that this time, action would not only be verbal: rather, people would also actually take up the task at the local level, taking into account the existing financial capacities and capacities in personnel.

M.P. Kogtikova states that for the first time, only with this survey operation in 1939 were various complicating factors and distance of the land from the kolkhoz actually eliminated, noting that before 1939 only a very small number of kolkhozes in the non-Black Earth Region had had crop rotation available. At the beginning of 1941, these then numbered 32,531, yet this was even less than $15 \%$ of the total number of kolkhozes. All work activities during the transition to the 1940s were aimed at introducing grass-field systems. A fundamental improvement failed to materialise, because the grasses sown achieved only very low yields per hectare. Thus, the hoped-for positive effect on animal husbandry also failed to materialise, nor was there much improvement in soil fertility. ${ }^{104}$

Difficulties arose from 1938 on in the employment of farming technology. The supply of news tractors flagged from 1937 on due to the upturn in armaments production, and the supplying of trailed implements and combine harvesters slowed from 1938 onwards. This impacted on the performance capability of agriculture, and fieldwork was significantly 
compromised. Now the wasteful way in which the sparse resources had been handled, the result of an absence of strict budgetary restrictions, took its revenge. ${ }^{105}$ It drastically limited the service life of the farming technology that had been supplied in comparison with Western agriculture, and forced Soviet agriculture to rely on constant inputs. As a result of poor maintenance and the extremely high rate of fluctuation among tractorists and drivers of harvester combines, even the number of serviceable tractors and land machines declined from 1938 on. The rationing of fuel was an additional factor that served to exacerbate problems.

Eikhe had already warned in early 1938 about the growing discrepancy between supply of tractors and provisioning of service facilities for their repair. Of the 5,819 MTS, 2,088 had no workshop, and only 1,200 were equipped to carry out larger-scale repairs. Eikhe noted that while Stalin had given priority in 1934 to regular and smaller-scale repairs, "wreckers" had sabotaged the regular continual maintenance. Many tractors were now in need of fundamental repairs. ${ }^{106}$ By contrast, Benediktov in 1939 regarded the insufficient provision of investment funds by Gosplan as the main reason why the construction of economic and residential buildings for the MTS had fallen far behind in the past several years. He stated that there was still a lack of 1,400 MTS workshops for regular repairs, and 3,500 MTS had no heated parking areas for their cars. Some $40 \%$ of the tractors and harvester combines also had to be left out in the open during the winter, since no shelters were available. He also noted that there had been just as little concern when it came to the living conditions of the tractorists and harvester combine operators. The MTS were very poorly equipped with apartments and facilities for the everyday needs of the workers. ${ }^{107}$ In addition, Benediktov noted, many MTS units had no storage tanks for fuel. This was causing huge losses. Consequently, Gosplan would have to at least double the projected budget allocation for the Third Five-Year-Plan. ${ }^{108}$

The poor maintenance condition of the tractors and the delayed delivery of fuel and seed material resulted in numerous accidents and long periods of idleness. This impacted on the quality of the seeding: in many instances, the required measures for agro-technology were not adhered to and low-quality seed material was used. The seeding norm was lowered, and in poorly cultivated fields, sowing was regionally done by hand. ${ }^{109}$ Corresponding problems beset the harvest. Thus, in the summer of 1938, the NKVD reported on difficulties encountered in deployment of harvester combines due to their poor state of repair, the absence of spare parts and a high level of fluctuation among the drivers. The report noted that transport of the grain from the fields was also poorly organised. ${ }^{110}$ Grain spoiled because it was left to lie unprotected along the railroad tracks. ${ }^{111}$ Gosplan pointed to another cause for the high level of harvest losses in 1939, namely that the harvester combine drivers bore no material responsibility for the quality of their work. Moreover, they were even given a special prize while they caused high levels of losses. Thus, a driver was granted a special award at the All-Union Agricultural Exhibition because over the span of 22 days, he had harvested 717 hectares. But the actual harvest loss on his fields had amounted to $3.2 \mathrm{dt} /$ ha grain (and thus almost half of the "biological" harvest). ${ }^{112}$

\section{9-The plans for reshaping nature, 1940/1941}

In a phase when investments were concentrated on the armaments sector, between 1939 and 1941 extensive measures were launched across a broad area to reshape nature. They 
entailed inter alia the draining of huge swampy areas in the west together with a new "non-Black Earth Region programme." In the east, there were efforts centred on turning the steppe into a fertile oasis. ${ }^{113}$ In all regions, forage production was to be placed under state regulation in order to develop livestock farming in the kolkhozes. German agrarian experts noted for posterity, after German troops had invaded Belorussia, that these plans had begun to be implemented. They were clearly impressed by the work done in the previous months there in the draining of swamps. ${ }^{114}$ Thus, immediately prior to the German attack in June 1941, an extensive programme to reshape agriculture had been launched. As a caesura, it is certainly comparable with collectivisation. After ten years, the structures that had arisen were to be reshaped in such a manner that hectare yields and animal performance levels would be able to increase. The directive that land areas were to be designated for planting forage guaranteed that the area for grain cultivation would remain an embittered political contentious issue, because every such reduction also lowered the amount of grain that was to be delivered to the state by the kolkhozes as a tax in kind.

51 The regional more precise crop rotations announced by Benediktov were instituted in 1940 and 1941. The decrees leave no doubt that the initially promised shifting of the freedom of decision to the kolkhozes did not materialise. Rather, the crop rotations continued to be centrally stipulated and controlled. The respective regional total area for the individual cultures was prescribed mandatorily by law. From 1942 on, there were once again central plans for sowing that would serve simultaneously as the basis for the obligatory deliveries to the state for the individual kolkhozes. Thus, once again the need for control triumphed over the freedom of decision by the enterprise, which was deemed absolutely essential by the experts for increasing per hectare yield.

The first corresponding decree was issued on 5 March 1940 for the Ukraine. ${ }^{115}$ It formulated as its goal to create a "solid forage basis," to fulfil the prerequisite for a complex mechanisation, and to increase the land areas under garden cultivation, viticulture and perennial plantings. In the dry areas, it prescribed the planting of forest protection strips to guard against wind erosion. The introduction of crop rotations was to proceed hand in hand with land improvement and breaking new ground. ${ }^{116}$ The law stipulated centrally the extent of cultivation area according to cultures for Ukraine. After a very brief transition period for the introduction of their crop rotations, the kolkhozes were ordered to achieve these goals already in 1942. For that reason, the sowing plan 1942 for the entire Ukraine was immediately appended to the law as an enclosure. ${ }^{117}$ The archival material indicates that behind the scenes once again, the principal issue of contention was the extent of the area for sowing grain. Here the party achieved a "compromise": namely that the area for grain cultivation from 1942 on should reach the extent it had attained in 1937. By that point in time, the total area should be expanded through newly reclaimed land. ${ }^{118}$ The crop rotations of the individual kolkhozes had to be accommodated into the framework of the plan for cultivation. In keeping with this, the local authorities continued even in 1940 to dispose over the kolkhoz land ad libitum and to separate it off for diverse and sundry purposes. It was only the bureaucratic path that had now become somewhat more complicated. The local violation of law now had to be brought to the attention of the NKZ and then be approved by the government. ${ }^{119}$ The law prescribed the relocation of important private plot production branches into the kolkhozes. In order to accomplish that successfully, the state would have had to make substantial funding available for these highly labour-intensive spheres - including animal 
husbandry, fruit and vegetable production - and would have had to offer the kolkhozniki material incentives for their additional labour. Yet Stalin was as little ready to do that in 1940 as he had been at the beginning of forced collectivisation in 1929. The elevation of agriculture and increasing of per hectare yields would continue to be based principally on state measures of compulsion. To the extent that in individual cases, "material incentives" were promised, those incentives could not become effective due to adherence to the "calculation of the biological harvest." Under the most favourable circumstances, the losses of what had matured on the "stalk" and was thus registered as "official harvest" amounted to $20 \%$ of what was brought in from the fields and ended up in the kolkhoz barns. But it was impossible to distribute what had not been gathered in from the field. For that reason, a natural distribution "in kind" of the "additional yields" did not as a rule occur, neither for potatoes nor for grain. ${ }^{120}$

\section{0-General findings : The paradox of state action in the field of agricultural policy}

53 From the time of the 1906 Stolypin agrarian reforms on, the state had interfered actively in production in order to decrease the level of backwardness that had existed at the starting point baseline vis-à-vis Western Europe. The Soviet Union was thus able to build on a policy of state intervention to increase yields and improve agricultural technology. In 1929, a serious shift occurred in this relation. Now emphasis was placed principally on measures of state compulsion for pressing ahead with agrarian modernisation instead of offering incentives and credits to spur change. The state issued directives without desiring any longer to bear the costs for creating the material prerequisites for the realisation of those orders. It neither provided the required investment funding under Stalin nor did it pay the agrarian enterprises the producer prices required to cover costs of production-money with which the enterprises might have been better able to remunerate their workers and generate funds for further investment. Rather, the party demanded "tribute" from the peasant farmers for industrialisation. In Stalin's eyes, they scarcely differed from class enemies. It was not until Brezhnev's era that the state commenced with its crucially necessary material support for increasing yields per hectare and bettering animal performance.

54 From 1929 on, in a paternalising manner, the Soviet state decided over the heads of the agricultural producers in every respect. In so doing, it stripped them of the latitude to decide for themselves about the improvements in cultivation technology deemed necessary. The state was unconcerned here about the consistency of its directives from on high. Consequently, it insisted on a substantial proportion of the cultivation area devoted to grain, even though the transition to scientifically grounded crop rotations necessarily had to actually diminish the area for grain cultivation. The kolkhozes did not achieve any independence as enterprises nor did they attain any degree of self-responsibility. The loss of their own tractive power due to the demise of the work horses brought about by state decree rendered them totally dependent in field work operations on the farming technology of the machine-tractor stations (MTS). They thus lost control over the time scheduling and quality of their work in the fields; in addition, the effectiveness of that work declined. A rapid increase in yields would have presupposed autonomous agricultural enterprises that, working under the local conditions, could decide themselves about the optimal use of improved agricultural 
technology and crop rotations. Moreover, in 1929, the decisive bond between wages and quality of work performance was ruptured and lost. The agents of the state often punished good-quality work by repeatedly imposing additional burdens on the kolkhozes that were performing better, and did this despite the extant prohibition on that introduced in 1932. In effect, the incentive system generally rewarded poor work in the fields, because the fulfilment of the MTS plan was evaluated according to area, speed of completion and economising on fuel, but not according to actual yields per hectare on the fields under cultivation. The kolkhozes were required to make the deliveries of natural produce in kind to the MTS independent of the quality of the work. Thus, all the informal institutions of the Soviet command economy in the countryside required violation of the demands for agricultural technology officially articulated by the party and the state.

At the end of the 1920s, there were certainly a notable number of well-qualified agrarian experts. In their eyes, the interventions of the state seemed particularly absurd, since they were able to judge the negative consequences. Since in its official documents, the state adhered to the goals of improving agricultural technology and the introduction of crop rotation, the state was dependent on the agronomists. Only those experts were able to develop the downright "bacchanalian" plans behind which the party leadership managed to conceal its dilettantism in the practical management of agricultural production. The discrepancy between the optimistic images of the future sketched in the plans and the realities in the enterprises on the ground could not have been greater. In the 1930s as well, many experts adhered to their conviction that any improvement in agricultural technology and the introduction of crop rotations presupposed the active involvement of the agricultural producers themselves. But to the extent that locally on the ground they bore the responsibility for implementing agrarian modernisation, they stood confronting a dilemma. Either they followed their conscience as agrarian experts and introduced crop rotations, which would have led to a notable increase in yield per hectare, while concomitantly disregarding and thus violating the state order for a large area of grain sowing. Or they violated their professional honour in their work on the spot in order to avoid state measures of repression. Given their deplorable situation, most appear to have deserted the village. The party under Stalin misused the agricultural experts, branding them as scapegoats for the failure of the "revolutionising of the agricultural productive forces" to materialise. After the poor harvest of 1936, which exposed Stalin's promise of a "prosperous" life as a lie and revealed the weaknesses of "Socialist agriculture," the party leadership chose in 1937 to denigrate the agrarian experts before the eyes of the population as "wreckers" and "enemies of the people," who intentionally had sabotaged their directives. Many agronomists became victims in 1938 of the "great terror," including all the previous People's Commissars for Agriculture of the USSR: Iakovlev, Chernov and Eikhe. Just like their more fortunate successor Benediktov, they all shared, at least in their basic approach, the conviction of the experts: namely that an increase in per hectare yields presupposed the active participation of the agricultural producers in the agrarian enterprises.

The Soviet project under Stalin resulted in a negative spiral that led to a lasting blockage of any increase in yields. The major factor here was that the motivation of the agricultural producers was lost, gambled away. Under Stalin the state demanded of the peasants that they should work seemingly as serfs in the field, performing bonded labour that went largely unpaid. An increase in work input in grain and potato cultivation increased only their own self-exploitation, but not their income. For the kolkhozes, the 
expansion of grain cultivation entailed an increase in losses for the enterprise. The assessment of the radical reformers at the end of the 1980s that the collectivisation had turned the farmers into agricultural labourers who had lost interest in the results of their work thus leads to the crux of the problem. ${ }^{121}$ In Soviet agriculture, there definitely was no lack of labour. The striking lack of efficient farming technology under the Soviet command economy has already been taken into due account in this statement. The supposed "felt" lack of labour can be explained by the absence since 1930 of any real motivation to work. This had a lasting formative impact on Russian economic culture and has still not been overcome today.

In 1939, Benediktov, like the experts of the Organisation Production School before, spoke once again about the necessity of bringing in the agricultural producers themselves as active participants, and carrying out agricultural modernisation supported by and relying on them. Why then was there so little of this in evidence in his own practical actions? That probably can only be explained by the peculiarities of political communication under the dictatorship, so-called "regressive learning." 122 Benediktov's words contradicted his deeds. Evidently he had been granted the mercy of not having to consciously recognise that. A crop rotation from the bottom up, determined by the enterprises, excluded the possibility of setting exact figures in advance for the total cultivation area of the economic region. It was reserved to young researchers after Stalin's death, such as the later prominent sociologist Tatiana Zaslavskaia, and the agrarian economist Gelii Shmelev, who likewise garnered national recognition in the era of Perestroika, to state that by their labour, the kolkhozniki evidently extracted value from the agricultural products, because through their labour these products became cheaper!

\section{NOTES}

1. See Stephan Merl, "Handlungsspielräume und Sachzwänge in der sowjetischen Wirtschaftsund Sozialpolitik der Zwischenkriegszeit," in Wolfram Fischer, ed., Sachzwänge und Handlungsspielräume in der Wirtschafts- und Sozialpolitik der Zwischenkriegszeit (St. Katharinen: Scripta Mercaturae Verlag, 1985), 175-229; Stephan Merl, "Hat sich der landwirtschaftliche Großbetrieb bewährt? Zum Vergleich von Agrarentwicklung und Agrarproblemen in der Sowjetunion und der DDR," in Hannelore Horn, Wladimir Knobelsdorf and Michal Reiman, eds., Der unvollkommene Block: Die Sowjetunion und Ost-Mitteleuropa zwischen Loyalität und Widerspruch (Berlin : Berlin-Verlag, 1988), 139-170.

2. See Katja Bruisch, Als das Dorf noch Zukunft war: Agrarismus und Expertise zwischen Zarenreich und Sowjetunion (Cologne et al. : Böhlau Verlag, 2014), 179-257 ; George L. Yaney, The Urge to Mobilize : Agrarian Reform in Russia, 1861-1930 (Urbana: University of Illinois Press, 1982) ; Merl, "Handlungsspielräume und Sachzwänge."

3. See Stephan Merl, "Einleitung," in idem, ed., Sowjetmacht und Bauern: Dokumente zur Agrarpolitik und zur Entwicklung der Landwirtschaft während des "Kriegskommunismus" und der Neuen Ökonomischen Politik (Berlin : Duncker \& Humblot, 1993), 15-78. 
4. Cf. Stephan Merl, Die Anfänge der Kollektivierung in der Sowjetunion : Der Übergang zur staatlichen Reglementierung der Produktions- und Marktbeziehung im Dorf (1928-1930) (Wiesbaden : Otto Harrassowitz, 1985), 166-213.

5. See Merl, "Hat sich der landwirtschaftliche Großbetrieb bewährt?"

6. See R.W. Davies, "The Soviet Rural Economy in 1929-1930. The Size of the Kolchoz," in C. Abramsky, ed., Essays in Honour of E.H. Carr (London : Macmillan, 1974), 255-280 ; Merl, Die Anfänge der Kollektivierung in der Sowjetunion, 331-369.

7. Merl, Die Anfänge der Kollektivierung in der Sowjetunion, 365-369.

8. On the "kolkhoz giants" in connection with the settlement of nomads in Kazakhstan, which resulted in many victims, see Robert Kindler, Stalins Nomaden: Herrschaft und Hunger in Kasachstan (Hamburg : Hamburger Edition, 2014) ; Niccolo Pianciola, "Famine in the Steppe : The collectivization of agriculture and the Kazak herdsmen 1928-1934," Cahiers du Monde russe, 45, 1-2 (2004) : 137-192.

9. Piatiletnii plan narodnogo-khoziaistvennogo stroitel'stva SSSR [Five-year plan for the construction of the national economy of the USSR], vol. 2 (M. 1930), 338.

10. See Ibid.; Merl, "Handlungsspielräume und Sachzwänge," 184-211; Merl, Die Anfänge der Kollektivierung in der Sowjetunion, 237-241, 370-400.

11. Cf. R.W. Davies, The Industrialisation of Soviet Russia, vol. 1 : The Socialist Offensive. The Collectivisation of Soviet Agriculture 1929-1930 (London: Macmillan, 1979); Stephan Merl, Bauern unter Stalin: Die Formierung des sowjetischen Kolchossystems 1930-1941 (Berlin: Duncker \& Humblot, 1990), 61-128 and 199-221 ; Davies, "Rural Economy" ; Merl, Die Anfänge der Kollektivierung in der Sowjetunion, 331-400.

12. Merl, Bauern unter Stalin, 128-140 ; on Stalin's sense of insecurity as a result of the severe economic crisis of 1932, see also R.W. Davies and Oleg Khlevnyuk, "Stakhanovism and the Soviet Economy," Europe-Asia Studies, 54, 6 (2002) : 867-903.

13. See Otto Schiller, "Die Hungersnot in der Sowjetunion," in D. Zlepko, ed., Der ukrainische Hunger-Holocaust : Eine Dokumentation (Sonnenbühl : Wild, 1988), 189-204, here, 203.

14. See Merl, Bauern unter Stalin, 129-140, 260-280, 360-371, and 453-476 ; Stephan Merl, "Bilanz der Unterwerfung - die soziale und ökonomische Reorganisation des Dorfes," in Manfred Hildermeier, ed., Stalinismus vor dem Zweiten Weltkrieg: Neue Wege der Forschung (Munich : Oldenbourg Verlag, 1998), 119-145.

15. Merl, "Bilanz der Unterwerfung," 140-141; Merl, Bauern unter Stalin, 327-417.

16. Cf. Robert F. Miller, One Hundred Thousand Tractors: The MTS and the Development of Controls in Soviet Agriculture (Cambridge: Harvard University Press, 1970); Stephan Merl, "Agrarpolitik und Bauernschaft im Nationalsozialismus und im Stalinismus," in Matthias Vetter, ed., Terroristische Diktaturen im 20. Jahrhundert : Strukturelemente der nationalsozialistischen und stalinistischen Herrschaft (Opladen : Westdeutscher Verlag, 1996), 118-156.

17. Stephan Merl, Sozialer Aufstieg im sowjetischen Kolchossystem der 1930er Jahre ? Über das Schicksal der bäuerlichen Parteimitglieder, Dorfsowjetvorsitzenden, Posteninhabern in Kolchosen, Mechanisatoren und Stachanowleute (Berlin : Duncker \& Humblot, 1990).

18. Merl, "Agrarpolitik und Bauernschaft," 153-156.

19. See Merl, "Hat sich der landwirtschaftliche Großbetrieb bewährt ?"

20. See Merl, Bauern unter Stalin, 40. Likewise from a long-term perspective, the evaluation of the performance of the large-scale Soviet enterprises is unfavourable.

21. Merl, Bauern unter Stalin, 371-390.

22. Merl, Bauern unter Stalin, 377-383.

23. See Muralov, "Deputy People's Commissar for Agriculture of the RSFSR," Sotsialisti-cheskoe zemleustroistvo, no. 1 (1932) : 1.

24. M. Holendo, "Die Politik der KPdSU im Dorf," Kommunistische Internationale, 12-13 (1930) : 674 ; see also Merl, "Handlungsspielräume und Sachzwänge," 184-211. 
25. Merl, Die Anfänge der Kollektivierung in der Sowjetunion, 391-397.

26. Merl, "Bilanz der Unterwerfung," 131-137.

27. Moisei Vol'f (1880-1933) was from 1930 Deputy People's Commissar for State Farms. On his reservations, see Pravda, 6 June and 11 July 1928, in Merl, ed., Sowjetmacht und Bauern, Dok. 57, 487-493.

28. Merl, Bauern unter Stalin, 199-256.

29. A.V. Negadin, "Mobilizuemsia na razvertyvanie zemleustroitel'nykh rabot 1933 goda [Let us mobilise for the expansion of land settlement activities in 1933]," Sotsialisticheskoe zemleustroistvo, no. 1 (1933) : 1 .

30. Negadin, "Mobilizuemsia na razvertyvanie zemleustroitel'nykh rabot 1933 goda," 43-48; Miller, One Hundred Thousand Tractors.

31. Merl, Bauern unter Stalin, 36-37.

32. "Decree, Council of the People's Commissariats (SNK) and the Central Committee (TsK), 3 Sept. 1932, Sobranie zakonov o rasporiazhenii (SZ) [Collection of laws and instructions] 1932, no. 66 , art. 388 .

33. Cf. on this likewise Bruisch, Als das Dorf noch Zukunft war, 224-257.

34. "Resolution of the NKZ, RSFSR, 14 May 1933 on the "Preliminary Results of the Introduction of Crop Rotations in Kolkhozes," Sotsialisticheskoe zemleustroistvo, no. 13-14 (1933) : 10-11.

35. F.P.Zelenin, "Ocherednye zadachi po vnutrikolkhoznomu zemleustroistvu i vvedeniiu sevooborotov [The next tasks for land settlement within collective farms and the implementation of crop rotations]," Sotsialisticheskoe zemleustroistvo, no. 10 (1935) : 5-9.

36. RGAĖ (Rossiskii gosudarvennyi arkhiv èkonomiki - Russian State Archive of the Economy), f. 9490 , op. 1 , d. $58,1.86-106$.

37. RGAE், f. 9490, op. 1, d. 63.

38. Merl, Bauern unter Stalin, 247-256.

39. See Naum Jasny, The Soviet Industrialization : 1928-1952, (Chicago : University of Chicago Press, 1961).

40. J.V. Stalin, "Rede auf der Ersten Unionsberatung der Stachanovleute am 17.11.1935," in idem, Fragen des Leninismus (Berlin 1970), 603-604 ; Karen Petrone, Life Has Become More Joyous, Comrades : Celebrations in the Time of Stalin (Bloomington : Indiana University Press, 2000).

41. Vtoroi vsesoiuznyi s"ezd kolkhoznikov-udarnikov 11-17 fevralia $1935 \mathrm{~g}$. Stenograficheskii otchet [Second All-Union Congress of Kolkhoz Shockworkers, 11 - 17 february 1935 : Stenographic report] (M, 1935), 5-6.

42. Vtoroi vsesoiuznyi s"ezd kolkhoznikov-udarnikov 11-17 fevralia 1935 g., 9-39.

43. Vtoroi vsesoiuznyi s"ezd kolkhoznikov-udarnikov 11-17 fevralia 1935 g., 11-13.

44. SZ 1935, no. 11, Art. 82. The $2^{\text {nd }}$ Kolkhoz Congress included the addition "i.e. in perpetuity".

45. Decree, SNK and TsK, 25 Feb.1935, SZ 1935, no. 18, art. 139.

46. Decree, SNK SSSR of 7 July 1935, SZ 1935, no. 34, art. 300.

47. See SZ, 1935, no. 37, 48 and $65 ; 1936$, no. 10, 15, 16 and $40 ; 1937$, no. 16.

48. SZ 1936, no. 40, Art. 346 ; for Kazakhstan : 1937, no. 4, art. 7.

49. Report, 28 Sept. 1936 to the Commission for Party Control (KPK) in the Central Committee regarding the Implementation of the resolution by the TsK and SNK of 19 Dec. 1935, written by Alekseev, Deputy Representative of the KPK at the West Oblast', WKP (National Archives, Washington, Smolensk Party Archive), WKP 390, 1. 327-350.

50. Ia.A. Iakovlev, "Iz praktiki raboty partiinogo kontrolia [From the work experience of party control]," Bol'shevik, no. 6 (1936) : 64-77, here : 66-68.

51. M. Snegirev, "Zadachi i metody ucheta zemel' kolkhozov [The tasks and methods of kolkhoz land accounting]," Sotsialisticheskoe sel'skoe khoziaistvo, no. 10 (1939) : 32-42, here 34.

52. RGAE், f. 9490, op. 1, d. 115 : Stenogram of the consultation session, Kolkhoz Dept.

53. RGAÉ, f. 9490, op. 1, d. 115, 1. 1-3. 
54. RGAE், f. 9490, op. 1, d. 115, 1. 4-9.

55. Speech by Iakovlev before the June 1937 plenary of the Central Committee, "On Measures to Improve the Seed of Grain Cultures," Bol'shevik, no. 13 (1937) : 11-19, here 17-18.

56. See, for example, Sotsialisticheskoe Zemledelie, 24 and 28 Feb. and 21 April 1937.

57. Iakovlev, "On Measures to Improve the Seed of Grain Cultures," 11-12 ; Decree, SNK SSSR, 29 June 1937, SZ 1937, no. 40, Art. 168.

58. SZ 1937, Art. 168.

59. SZ 1937, Art. 168.

60. See Sotsialisticheskoe Zemledelie, 22 and 28 Sept. 1937.

61. Decree, SNK SSSR, 26 April 1938, SZ 1938, no. 21, art. 136.

62. Decree, SNK SSSR, 13 Sept. 1937, SZ 1937, no. 60, art. 261.

63. Sotsialisticheskoe Zemledelie, 14 Sept. 1937.

64. Sotsialisticheskoe Zemledelie, 9 Jan. 1938.

65. Information from the NKVD, 28 April 1938, on deficiencies in the spring sowing on 25 April 1938, in Tragediia sovetskoi derevni : Kollektivizatsiia i raskulachivanie. Dokumenty i materialy v 5 tomakh. 1927-1939 [The tragedy of the Soviet village: collectivisation and de-kulakisation. Documents and materials in five volumes. 1927-1939], vol. 5 (1937-1939), part 2 (1938-1939) (M. : ROSSPEN, 2006), doc. 47, 113-118.

66. "Memo, 4 March 1939," signed by the People's Commissar for Agriculture, Benediktov, on the draft of the Third Five-Year Plan, Tragediia sovetskoi derevni, vol. 5, part 2, doc. 178, 360-373, here 372-373.

67. According to the decree, SNK and ZK, 10 August 1939 (Sobranie zakonov 1939, no. 47, Art. 360), the grain from selected seed areas could now be utilised "after total coverage of the demands for sowing and security" to satisfy the obligations of delivery to the state.

68. See, for example, Sotsialisticheskoe Zemledelie, 5 Feb., 5 April and 18 May 1940.

69. Stephan Merl, Politische Kommunikation in der Diktatur : Deutschland und die Sowjetunion im Vergleich, (Göttingen : Wallstein Verlag, 2012).

70. Nonetheless, this is indeed the argument advanced by Sheila Fitzpatrick, see her Stalin's Peasants : Resistance and Survival in the Russian Village after Collectivization (New York : Oxford University Press, 1994), 296-312.

71. Izvestiia, 6 April 1937.

72. Merle Fainsod, Smolensk under Soviet Rule (Boston : Unwin Hyman, 1958), 59-61.

73. WKP (cf. footnote 49) 238, 1. 211-214, extract, Minutes of the meeting of the West Obkom, 31 July 1937.

74. That is a typical phenomenon in political communication within a dictatorship, which can be interpreted as "regressive learning," see Merl, Politische Kommunikation in der Diktatur, 24-25.

75. M.A. Chernov, "O vvedenii pravil'nykh sevooborotov : Doklad na Plenume TsK VKP (b), Iiun' $1937 \mathrm{~g}$. [On the implementation of correct crop rotations : Speech at the plenum of the TsK VKP (b), June 1937]," Sotsialisticheskaia Rekonstruktsia Sel'skogo Khoziaistva, no. 7 (1937) : 25-34, here 26.

76. Chernov, "O vvedenii pravil'nykh sevooborotov...," 26-28, 33.

77. Report, NKVD, 29 Jan. 1939, on the basis of investigation materials for 1936-1938, Tragediia sovetskoi derevni, vol. 5, part 1, appendix 2, 550-571.

78. Report, NKVD, 29 Jan. 1939, Tragediia sovetskoi derevni, vol. 5, part 1, appendix 2, 551. On the so-called "wrecker activity" in connection with selected seeds, see ibid., 555-558.

79. Tragediia sovetskoi derevni, vol. 5, part 1, appendix 2, 551, 558f., 562-566, 568.

80. Eikhe, 18 Jan. 1938, before the January TsK plenary, Tragediia sovetskoi derevni, vol. 5, part 2, doc. 3,31 .

81. See Merl, Bauern unter Stalin, 234-242 ; Report, NKVD, 3 Jan. 1937, from Oblast' Orenburg, Tragediia sovetskoi derevni, vol. 5, part 1. doc. 5, 77-79. 
82. See Merl, Bauern unter Stalin, 247-256. On the prohibition of exclusions from kolkhozes, see : Tragediia sovetskoi derevni, vol. 5, part 2, doc. 30, 79-81, and doc. 42, 100-102.

83. Decree, SNK and TsK, 19 April 1938, on the "incorrect distribution of incomes in the kolkhozes," Sobranie postanovlenii i rasporiazenii pravitel'stva SSSR 1938 [Collection of acts and instructions of the government of the USSR], no. 18, Art. 116 ; see also Merl, Bauern unter Stalin, 386-391.

84. Speech by Stalin, 22 May 1939 at the TsK plenary on questions pertaining to the construction of the kolkhoz, Tragediia sovetskoi derevni, vol. 5, part 2, doc. 206, 416-424.

85. Speech by Stalin, 22 May 1939, Tragediia sovetskoi derevni, vol. 5, part 2, doc. 206, 417.

86. Speech by Stalin, 22 May 1939, Tragediia sovetskoi derevni, vol. 5, part 2, doc. 206, 420.

87. Merl, Bauern unter Stalin, 247-256 and 386-391.

88. Tragediia sovetskoi derevni, vol. 5, part 2, doc. 208, 27 May 1939, point 5, 427.

89. Stéphane A. Dudoignon and Christian Noack, eds., Allah's kolkhozes: Migration, De-Stalinisation, Privatisation and the New Muslim Congregations in the Soviet Realm (1950s-2000s) (Berlin : Klaus Schwartz Verlag, 2014).

90. See Merl, Bauern unter Stalin, 191-197; M.P. Kogtikova, Ukreplenie zemlepol'zovaniia kolkhozov v 1938-1941 gg. [The consolidation of the land-use of collective farms, 1938-1941] (M. : ms. diss., 1965).

91. Report, Gosplan, 8 April 1938 to Stalin et al., Tragediia sovetskoi derevni, vol. 5, part 2, doc. 37, 90-97.

92. Izvestiia, 12 March 1941 ; Merl, Bauern unter Stalin, 371-417. For annual reports of the kolkhozes, see : RGAĖ, f. 7486, op. 7.

93. Decree, SNK and TsK, 28 Dec. 1939, SZ 1940, no. 1, Art. 3.

94. Decree, SNK and TsK, 28 Dec. 1939, SZ 1940, no. 1, Art. 3.

95. See Merl, Bauern unter Stalin, 327-417. Campaigns from 1935 on repeatedly castigated the indebtedness of the state organs toward the kolkhozes.

96. Merl, Politische Kommunikation in der Diktatur. If Benediktov continued to attribute many problems to the activity of "enemies of the people", he was making use of the official discourse of his time.

97. "Memo, 4 March 1939," 360-373 (see footnote 66).

98. "Memo, 4 March 1939," 360-373 (see footnote 66).

99. Josef Stalin, "Neue Verhältnisse - Neue Aufgaben des wirtschaftlichen Aufbaus. Rede auf der Beratung der Wirtschaftler, 23. Juni 1931," idem, Werke, vol.13 (Frankfurt/M.: Druck-Verlags-Vertriebs-Kooperative, 1972), 47-72.

100. “Memo, 4 March 1939," 368.

101. Tragediia sovetskoi derevni, vol. 5 , part 2, doc. 187, 384-387.

102. "Memo, 4 March 1939," 366-369.

103. "Memo, 4 March 1939," 366-369. On the directives issues in 1940-1941 for the individual regions, see below, sec. 9, The Plans for Reshaping Nature.

104. Kogtikova, Ukreplenie zemlepol'zovaniia kolkhozov v 1938-1941 gg.

105. On this, see János Kornai, Economies of Shortage, 2 vols. (Amsterdam : North-Holland, 1980).

106. Eikhe, 18 Jan.1938, before the TsK January plenary, Tragediia sovetskoi derevni, vol. 5 , part 2, 31 .

107. “Memo, 4 March 1939," 371-373.

108. "Memo, 4 March 1939," 372-373.

109. NKVD, on the spring sowing, 28 April 1938, Tragediia sovetskoi derevni, vol. 5, part 2 , doc. $47,113-118$.

110. NKVD to Ezhov, 25 July 1938, Tragediia sovetskoi derevni, vol. 5, part 2, doc. 72, 171-172.

111. Report from Beriia, 23 Oct. 1938 to Stalin, Molotov and Ezhov, Tragediia sovetskoi derevni, vol. 5, part 2, doc. 137, 293- 294 ; doc. 158 (31 Dec. 1938), 326-327. 
112. Gosplan on the harvest yields 1939, Tragediia sovetskoi derevni, vol. 5, part 2, doc. 246 , 500-512, here 502-505.

113. Cf. Inter alia the decree, SNK and TsK, 4 Jan.1939 on the expansion of the winter sowing and measures to increase yields per hectare in the eastern regions, Tragediia sovetskoi derevni, vol. 5, part 2, doc. 161, 330-333 ; SZ 1939, no. 3, Art. 10.

114. Von Poletika, "Lagebericht nach Reise im Juli 1941" and "Wirtschaftsstab Ost. Kurzes Konzept. Reisebericht 24.-27.7.1941," in W.P. von Poletika Collection, Hoover Institution, Stanford.

115. Decree, SNK SSSR, 5 March 1940, SZ 1940, no. 5, Art. 149. Corresponding decrees were issued for several economic regions.

116. Decree, SNK SSSR, 5 March 1940, SZ 1940, no. 5, Art. 149.

117. Decree, SNK SSSR, 5 March 1940, SZ 1940, no. 5, Art. 149. In this connection, by 1942 public gardens were to be laid out in every kolkhoz.

118. RGAÉ, f. 7486, op. 1, d. 2611, on the dispute between the planning drafts of the NKZ, the SNK, Ukraine and the Mikoian Commission.

119. See, for example, RGAE், f. 7486, op. 1, d. 2620 for the Oblast' Smolensk.

120. See RGAÉ, f. 7486, op. 7, for example, d. 141-143 and 173 (1941-1943).

121. See Stephan Merl, "Steht die Privatisierung der sowjetischen Landwirtschaft bevor?" Deutsche Studien, 28, 4 (1990) : 289-305.

122. See Merl, Politische Kommunikation in der Diktatur, 24-25.

\section{ABSTRACTS}

This article seeks to explore why the Soviet Union failed to achieve the two aims associated with the transition to "Socialist agriculture," namely the industrialization of agricultural production and a rapid increase in agricultural yields. In the 1930s, the party leadership under Stalin launched four large-scale campaigns for the implementation of these aims. These included land consolidation, the introduction of progressive crop rotation and the use of selected seeds. The paper describes what informal institutions acted to deter the agricultural producers and those officials with relevant responsibility in the Soviet party and state bureaucracy from introducing crop rotations, and why agricultural producers under Stalin lost interest in increasing per hectare yields. The study reveals the contradiction-ridden character of Stalin's agrarian policy and highlights its long-term consequences.

Cet article étudie les raisons pour lesquelles l'Union soviétique a failli dans la concrétisation de deux objectifs qui devaient permettre la transition vers "l'agriculture socialiste ", à savoir l'industrialisation de la production agricole et une augmentation rapide des rendements. Dans les années 1930, la direction du parti sous l'égide de Stalin lança quatre grandes campagnes pour mener à bien ces objectifs. Cela incluait le remembrement des terres, l'introduction progressive d'une rotation des cultures et l'utilisation de semences sélectionnées. L'article décrit quels organismes informels entrèrent en action pour dissuader les producteurs agricoles et les officiels responsables concernés - que ce soit au sein du parti ou dans l'administration -, d'introduire la rotation des cultures et pourquoi les producteurs agricoles d'alors perdirent tout intérêt à augmenter le rendement à l'hectare. L'étude révèle le caractère hautement contradictoire de la politique agricole de Stalin et souligne ses conséquences à long terme. 


\section{AUTHOR}

\section{STEPHAN MERL}

University of Bielefeld, smerl@uni-bielefeld.de 